\title{
Determination of Sex Based on the Morphometric Evaluation of the Proximal Tibia
}

\author{
Determinación del Sexo Basada en la Evaluación Morfométrica de la Tibia Proximal
}

\author{
Elizabete Regina Silva Lucena dos Santos ${ }^{1}$; Pedro Paulo Feitosa de Albuquerque ${ }^{2}$; \\ Priscilla Virgínio de Albuquerque ${ }^{3}$; Belisa Duarte Ribeiro de Oliveira ${ }^{4}$ \& Vitor Caiaffo ${ }^{5}$
}

LUCENA DOS SANTOS, E. R. S.; ALBUQUERQUE, P. P. F.; ALBUQUERQUE, P. V.; OLIVEIRA, B. D. R.; CAIAFFO, V. Determination of sex based on the morphometric evaluation of the proximal tibia. Int. J. Morphol., 36(1):104-108, 2018.

SUMMARY: Anatomic differences are found between human males and females. These characteristics of sexual dimorphism vary across populations and have important implications for the study of human evolution. Researchers have employed anthropological tools for the characterization of human cadavers in different states of decomposition using complete skeletons, isolated bones or even bone fragments. The aim of the present study was to differentiate males and females based on morphometric aspects of human tibias from the Brazilian population. Sixty pairs of adult human tibias were obtained from bone collection of the Anatomy Sector of the Department of Animal Morphology and Physiology of the Rural Federal University of Pernambuco, Brazil. Ten measurements were made on the joint face of the tibial plateau: Anteroposterior diameter of the joint surface of the medial condyle (APM), Transverse diameter of the joint surface of the medial condyle (TM), Anteroposterior diameter of the joint surface of the lateral condyle (APL), Transverse diameter of the joint surface of the lateral condyle (TL), Anterior transverse measure of inter-condyle area (ATI), Posterior transverse measure of inter-condyle area (PTI), Middle transverse measure of inter-condyle area (MTI), Anteroposterior measure of inter-condyle area (API), Anterior measure of intercondyle area (AI) and Posterior measure of inter-condyle area (PI). The median morphometric values for the males' proximal tibia were: APM - 4.707 \pm 0.406 ; TM - 3.024 \pm 0.307 ; APL - 4.023 \pm 0.414 ; TL - $3.405 \pm 0.323$; ATI - $3.365 \pm 0.425$; PTIc - $1.788 \pm 0.307$; MTI - 1.167 \pm 0.279 ; API - 5.140 \pm 0.377 ; AI $-2.865 \pm 0.249$ and PI - 2.297 \pm 0.344 . The median morphometric numbers for the female's proximal tibia were: APM - $4.334 \pm 0.317$; TM - 2.702 \pm 0.298 ; APL - 3.549 \pm 0.382 ; TL $-2.991 \pm 0.281$; ATI $-2.818 \pm 0.307$; PTI $-1.555 \pm 0.222$; MTI $-1.054 \pm 0.262$; API - $4.596 \pm 0.303$; AI $-2.565 \pm 0.21$; PI $-2.031 \pm 0.225$. All parameters measured showed values significantly higher (p $<0.05$ ) for the male's proximal tibia. The findings demonstrate sexual dimorphism in this leg bone, which can be used with considerable reliability for scientific and forensic purposes. The results of these studies can be useful in cases where other methods are not applicable, increasing the range of options for forensic investigation.

KEY WORDS: Morphometry; Tibia; Morphology; Anatomy.

\section{INTRODUCTION}

Morphometry entails measurements of distances between pairs of anatomically homologous points, tangent points or extremes of structures. It is the study of variations in measurements and correlations between such measurements (covariations). Morphometry is an important tool used in studies to understand the relationship of variables, such as age and sex, between organisms.

Morphological and morphometric differences between males and females are demonstrated through anatomic, biological and/or physiological analyses.
Regarding the morphology of the skeleton, differences detected in body structures can be essential to the determination of sex from the analysis of bones based on sexual dimorphism, which is evidenced by the dimensions of bone structures (Hsiao et al., 1996; Rogers, 2005). Indeed, the determination of sex based on skeletal characteristics plays a crucial role in forensic medicine and anthropology (Hsiao et al., 2010).

Not all structures of the human skeleton serve as a reference for metric methods used to define sex in

\footnotetext{
${ }^{1}$ Student of Master's Program in Morphotechnology, Universidade Federal de Pernambuco (UFPE), Recife, PE, Brazil.

${ }^{2}$ Department of Veterinary Medicine, Universidade Federal Rural de Pernambuco (UFRPE), Recife, PE, Brazil.

${ }^{3}$ Department of Animal Morphology and Physiology, UFRPE, Recife, PE, Brazil.

${ }^{4}$ Department of Physiotherapy, ASCES-UNITA, Caruaru, PE, Brazil.

${ }^{5}$ Nucleus for Life Sciences, Agreste Academic Center, UFPE, Caruaru, Brazil.
} 
anthropological examinations or forensic investigations (Walrath et al., 2004; Harvati \& Weaver, 2006). The bones most commonly used for this purpose are the mandible, skull, pelvis, long bone and scapula, especially in European and American populations. The skull and pelvis constitute the most often used and efficient sets of characters in morphological analyses and are extremely important to the identification of sex (Cunha, 2001; Oliveira Costa et al., 2016). Long bones also play an important role in the evaluation of sexual dimorphism (Azevedo, 2008).

The tibia is a long bone that supports a large part of the body weight and is directly related to movements of the lower limbs. This bone also has strong dimorphic characteristics. The proximal portion of the tibia expands, forming a surface to support the body weight, the force of which is transmitted through the femur. The medial and lateral condyles, intercondyle area and tibial tuberosity are located at this end of the tibia (Stranding, 2010). The proximal portion of the tibia can be used for the evaluation of the results of knee replacement surgery or other specialized treatments. Moreover, morphometry is a reliable method for the evaluation of structures in this region of the tibia for medical purposes (Gandhi et al., 2014). Morphometric variables are also important to forensics as a method for the identification of an individual based on his/her unique characteristics (Delwing, 2013).

Considering the importance of sexual dimorphism to the identification of skeletons for scientific, medical and forensic purposes, the aim of the present study was to investigate sexual dimorphism based on morphometric aspects of the tibial plateau from human bones obtained from individuals of the Brazilian population.

\section{MATERIAL AND METHOD}

Sixty pairs of human tibias (120 bones) from adult individuals of the Brazilian population were obtained from bone collection of the Anatomy Sector of the Department of Animal Morphology and Physiology of the Rural Federal University of Pernambuco, Brazil.

The inclusion criteria were intact bone with no signs of trauma or apparent anomalies from adult humans, since differences between sexes are only evident after puberty due to the influence of the environment, hormones and musculature (Almeida \& Costa, 1977). The exclusion criteria were any type of anomaly, an advanced state of deterioration at the measurement site (tibial plateau), signs of trauma and bone from individuals under the age of 18 years at the time of death.

Bones were obtained from individuals aged 15 to 98 years, but only those from individuals aged 18 years or older were used. The individuals had been buried between December 2009 and March 2012 and were exhumed between April and May 2014. All cadavers were obtained from the Santo Amaro cemetery located in the city of Recife, Brazil. The present study received approval from the ethics committee of the University of Pernambuco (certificate number: 1.307.166).

The pairs of tibias were identified, organized and numbered from 1 to 60 . The researcher in charge of the measurements analyzed the material in a randomized manner and had no information on the sex of each pair of tibias. After cleaning and sterilization, photographs were taken of the head of the tibial plateau with a digital camera (Canon®, model 40D) using a 55-mm lens. The highest portion of the plateau was positioned 21.3 centimeters from the lens of the camera, which was placed on a tripod.

Ten measurements were made on the joint face of the tibial plateau. A computational technique was employed using Image ${ }^{\circledR}$ version 1.47. The measurements were determined following the method described by Gandhi et al. (Fig. 1):

1. APM: Anteroposterior diameter of the joint surface of the medial condyle.

2. TM: Transverse diameter of the joint surface of the medial condyle.

3. APL: Anteroposterior diameter of the joint surface of the lateral condyle.

4. TL: Transverse diameter of the joint surface of the lateral condyle.

5. ATI: Anterior transverse measure of inter-condyle area.

6. PTI: Posterior transverse measure of inter-condyle area.

7. MTI: Middle transverse measure of inter-condyle area.

8. API: Anteroposterior measure of inter-condyle area.

9. AI: Anterior measure of inter-condyle area.

10. PI: Posterior measure of inter-condyle area.

Mean and standard deviation values were calculated for all measurements. The data were submitted to the Kolmogorov-Smirnov test using GraphPad Prism 5.01. The Student's t-test was used for the comparisons of means with normal distribution and the Mann-Whitney test was used for the comparisons of means with non-normal distribution. A $95 \%$ confidence level was used in all cases. Thus, p-values $<0.05$ were considered indicative of statistical significance. 


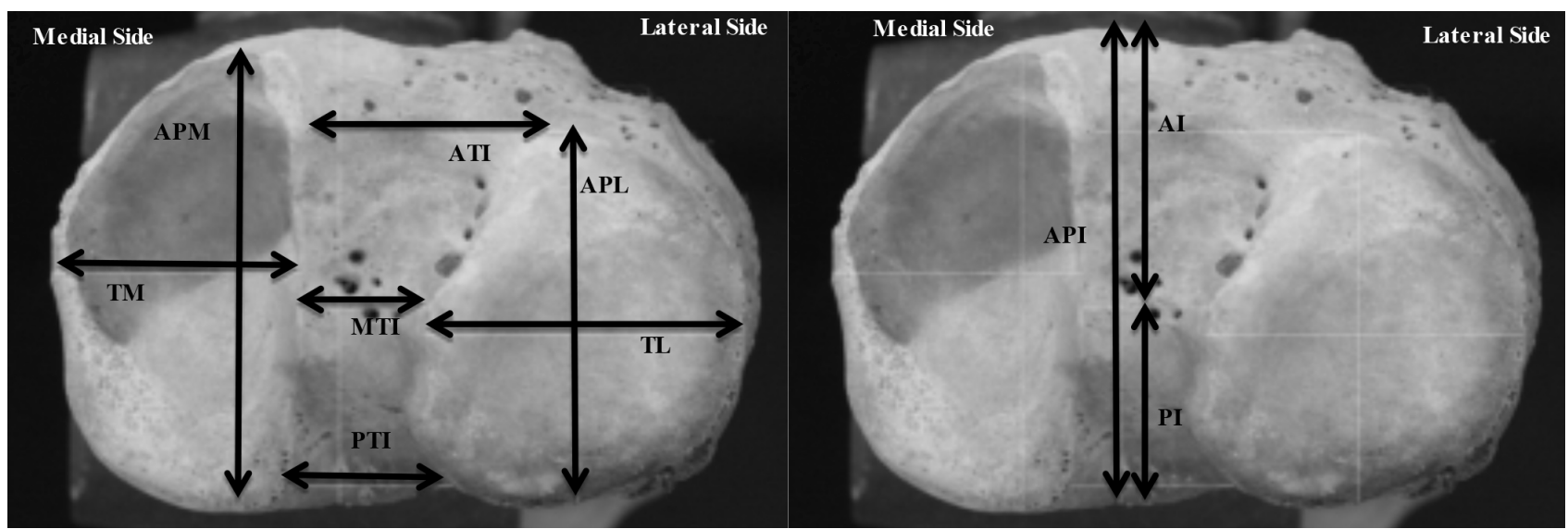

Fig. 1. Morphometric parameters made on proximal tibial plateau. APM: Anteroposterior diameter of the joint surface of the medial condyle; TM: Transverse diameter of the joint surface of the medial condyle; APL: Anteroposterior diameter of the joint surface of the lateral condyle; TL: Transverse diameter of the joint surface of the lateral condyle; ATI: Anterior transverse measure of inter-condyle area; PTI: Posterior transverse measure of inter-condyle area; MTI: Middle transverse measure of inter-condyle area; API: Anteroposterior measure of inter-condyle area; AI: Anterior measure of inter-condyle area; PI: Posterior measure of inter-condyle area.

\section{RESULTS}

After the application of the eligibility criteria, 42 bones (21 pairs) were excluded. Seventy-eight bones (39 pairs) were in adequate condition and were therefore included in the study. The values of the morphometric variables of the tibias were higher for the male sex compared to the female sex (Table I).

Table I. Values (in $\mathrm{cm}$ ) of morphometric variables of tibias from males and females and differences between sexes (data expressed as mean and standard deviation)

\begin{tabular}{lcccc}
\hline & $\begin{array}{c}\text { Male } \\
(\mathrm{cm})\end{array}$ & $\begin{array}{c}\text { Female } \\
(\mathrm{cm})\end{array}$ & $\begin{array}{c}\text { Difference } \\
\text { between sexes }(\mathrm{cm})\end{array}$ & $p$ \\
\hline APM & $4,707 \pm 0,406$ & $4,334 \pm 0,317$ & 0,373 & $<0.0001^{*}$ \\
TM & $3,024 \pm 0,307$ & $2,702 \pm 0,298$ & 0,322 & $<0.0001^{* *}$ \\
APL & $4,023 \pm 0,414$ & $3,549 \pm 0,382$ & 0,481 & $<0.0001 *$ \\
TL & $3,405 \pm 0,323$ & $2,991 \pm 0,281$ & 0,414 & $<0.0001^{* *}$ \\
ATI & $3,365 \pm 0,425$ & $2,818 \pm 0,307$ & 0,547 & $=0.0001^{* *}$ \\
PTI & $1,788 \pm 0,307$ & $1,555 \pm 0,222$ & 0,233 & $=0.0002^{* *}$ \\
MTI & $1,167 \pm 0,279$ & $1,054 \pm 0,262$ & 0,113 & $<0.0001^{* *}$ \\
API & $5,140 \pm 0,377$ & $4,596 \pm 0,303$ & 0,544 & $<0.0001^{*}$ \\
AI & $2,865 \pm 0,249$ & $2,565 \pm 0,210$ & 0,3 & $<0.0001^{* *}$ \\
PI & $2,297 \pm 0,344$ & $2,031 \pm 0,225$ & 0,266 & \\
\hline
\end{tabular}

* Statistically significant difference between male and female tibias using Mann-Whitney test

** Statistically significant difference between male and female tibias using Student's t-test

\section{DISCUSSION}

All measurements performed for the morphometric evaluation in the present study differed significantly between sexes. These findings demonstrate the usefulness of the tibia for the differentiation of sexes based on dimorphism. Moreover, the differences were not uniform, as the difference in some measurements had a broader range than other measurements. The main findings was the larger values for the male tibias compared to the female tibias, which is in agreement with data described in the literature (Mahfouz et al., 2012; Lim et al., 2013; Gandhi et al.). 
The largest differences in means between sexes were found for the anterior transverse measure of the inter-condyle area $(0.547 \mathrm{~cm})$ and anteroposterior measure of the intercondyle area $(0.544 \mathrm{~cm})$. Gandhi et al. reports similar results, with larger means in the male sex. Likewise, Mahfouz et al. found that the region of the knee was $5 \mathrm{~mm}$ larger, on average, in males than females. The smallest difference in means between sexes was found for the middle transverse measure of the inter-condyle area $(0.113$ $\mathrm{cm})$, which is in agreement with data reported by Gandhi et al. The mean differences for the other measurements ranged from 0.233 to $0.481 \mathrm{~cm}$.

Unlike research involving the pelvis and skull, few studies have investigated differences between sexual dimorphism through measurements of the tibia. However, studies have demonstrated differences between sexes using the pelvis, scapula and other long bones (Di Vella et al., 1994; Rabbi, 2000; Lim et al.; Mahfouz et al.; Gandhi et $a l$.). The aim of a large portion of morphometric studies involving the tibia is the delineation of the profile of the knee area or a description and differentiation of regions of the tibia in particular populations to provide a method for evaluating deformities in the knee region for medical purposes, such as guiding treatments and knee replacement surgeries (Kwak et al., 2007; Gandhi et al.; Moghtadaei et al., 2015).

In the present study, ethnicity was not taken into consideration in the evaluation of dimorphism. However, analyzing 1000 knees, Mahfouz et al. determined the existence of differences between sexes as well as ethnicities with regard to the morphology of the distal region of the femur and proximal region of the tibia. It has also been demonstrated that each population can have a distinct morphological pattern. Using computed tomography, Moghtadaei et al. performed a morphometric evaluation of the proximal area of the tibia in the Iranian population and compared the results to similar studies involving different populations (China, Korea, India and Japan), demonstrating differences among these groups. The fact that the Brazilian population has a highly miscegenated population could also translate to differences in such patterns in comparison to other population groups.

Like the tibia bone, in which sexual dimorphism was confirmed in the present study, other bones of the human skeleton exhibit differences between sexes. According to Azevedo, the bones of the pelvis and skull exhibit dimorphism. Indeed, researchers in Brazil and other parts of the world have dedicated themselves to the morphometric investigation of sexual dimorphism in such bones.

\section{CONCLUSION}

These findings demonstrate the differentiation of males and females through ten measurements on the tibial plateau, confirming the dimorphic potential of this long bone of the leg. Studies involving a morphometric analysis of the tibia for this purpose are scarce and further investigations of this type are needed, the findings can contribute to science in general and forensic science in particular. For example, the tibia bone could be used for sex determination of a victim in a criminal case.

LUCENA DOS SANTOS, E. R. S.; ALBUQUERQUE, P. P. F.; ALBUQUERQUE, P. V.; OLIVEIRA, B. D. R.; CAIAFFO, V. Determinación del sexo basada en la evaluación morfométrica de la tibia proximal. Int. J. Morphol., 36(1) :104-108, 2018.

RESUMEN: Se encuentran diferencias anatómicas entre hombres y mujeres. Estas características del dimorfismo sexual varían entre las poblaciones y tienen implicaciones importantes para el estudio de la evolución humana. Los investigadores han empleado herramientas antropológicas para la caracterización de cadáveres humanos en diferentes estados de descomposición utilizando esqueletos completos, huesos aislados o incluso fragmentos óseos. El objetivo del presente estudio fue diferenciar a hombres y mujeres basándose en aspectos morfométricos de las tibias humanas de la población brasileña. Se obtuvieron sesenta pares de tibias adultas en la recolección ósea del Sector de Anatomía del Departamento de Morfología Animal y Fisiología de la Universidad Federal Rural de Pernambuco, Brasil. Se realizaron diez mediciones en la cara articular de la meseta tibial: Diámetro anteroposterior de la superficie articular del cóndilo medial (APM), diámetro transversal de la superficie articular del cóndilo medial (TM), diámetro anteroposterior de la superficie articular del códilo lateral (APL), diámetro transversal de la superficie articular del cóndilo lateral (TL), medida transversa anterior del área intercondílea (ATI), medida transversal posterior del área intercondílea (PTI), medida anteroposterior del área intercondílea (API), medida anterior del área intercondílea (AI) y medida posterior del área intercondílea (PI). Los valores morfométricos medianos para la tibia proximal de los varones fueron: APM - $4.707 \pm 0.406$; TM - 3,024 $\pm 0,307$; APL $4,023 \pm 0,414$; TL - 3,405 $\pm 0,323$; ATI - $3.365 \pm 0,425$; PTI - 1,788 $\pm 0,307$; MTI - 1,167 $\pm 0,279 ;$ API - $5.140 \pm 0.377$; AI - 2,865 $\pm 0,249$ y PI $-2,297 \pm$ 0,344 . Los números morfométricos medianos para la tíbia proximal de la hembra fueron: APM - $4.334 \pm 0.317$; TM - 2,702 $\pm 0,298$; APL - 3,549 \pm 0,382 ; TL - 2,991 $\pm 0,281$; ATI - 2,818 $\pm 0,307$; PTI - $1.555 \pm 0.222$; MTI $1,054 \pm 0,262$; API $-4.596 \pm 0.303$; AI $-2,565 \pm 0,21$; PI $2.031 \pm 0,225$. Todos los parámetros medidos mostraron valores significativamente más altos $(\mathrm{p}<0,05)$ para la tibia proximal del varón. Los hallazgos demuestran dimorfismo sexual en este hueso de la pierna, que se puede utilizar con una fiabilidad considerable para fines científicos y forenses. Los resultados de estos estudios pueden ser útiles en casos donde otros métodos no son aplicables, aumentando el rango de opciones para la investigación forense.

PALABRAS CLAVE: Morfometría; Tíbia; Morfología; Anatomía.

\section{REFERENCES}

Almeida, A. J. \& Costa, J. B. O. Lições de Medicina Legal. 14 ${ }^{\text {th }}$ ed. São Paulo, Companhia Editora Nacional, 1977. 
LUCENA DOS SANTOS, E. R. S.; ALBUQUERQUE, P. P. F.; ALBUQUERQUE, P. V.; OLIVEIRA, B. D. R.; CAIAFFO, V. Determination of sex based on the morphometric evaluation of the proximal tibia. Int. J. Morphol., 36(1):104-108, 2018.

Azevedo, J. M. C. A. A Eficácia dos Métodos de Diagnose Sexual em Antropologia Forense. Tese Mestrado em Medicina Legal e Ciências Forenses. Lisboa, Faculdade de Medicina, Universidade de Lisboa, 2008.

Cunha, E. A Paleopatologia como Fator de Individualização em Antropologia Forense. Lição de síntese. Provas de agregação. Coimbra, Universidade de Coimbra, 2001.

Delwing, F. Análise do Dimorfismo Sexual em Adultos através de Medidas Cranianas. Tese Mestrado em Biologia Buco-dental. Piracicaba, Faculdade de Odontologia de Piracicaba, Universidade Estadual de Campinas, 2013.

Di Vella, G.; Campobasso, C. P.; Dragone, M. \& Introna, F. Jr. Skeletal sex determination by scapular measurements. Boll. Soc. Ital. Biol. Sper, 70(12):299-305, 1994.

Gandhi, S.; Singla, R. K.; Kullar, J. S.; Suri, R. K.; \& Mehta, V. Morphometric analysis of upper end of tibia. J. Clin. Diagn. Res., 8(8):AC10-3, 2014.

Harvati, K. \& Weaver, T. D. Human cranial anatomy and the differential preservation of population history and climate signatures. Anat. Rec. A Discov. Mol. Cell Evol. Biol., 288(12):1225-33, 2006.

Hsiao, T. H.; Chang, H. P. \& Liu, K. M. Sex determination by discriminant function analysis of lateral radiographic cephalometry. J. Forensic Sci., 41(5):792-5, 1996.

Hsiao, T. H.; Tsai, S. M.; Chou, S. T.; Pan, J. Y.; Tseng, Y. C.; Chang, H. P. \& Chem, H. S. Sex determination using discriminant function analysis in children and adolescents: a lateral cephalometric study. Int. J. Legal Med., 124(2):155-60, 2010.

Kwak, D. S.; Surendran, S.; Pengatteeri, Y. H.; Park, S. E.; Choi, K. N.; Gopinathan, P.; Han, S. H. \& Han, C. W. Morphometry of the proximal tibia to design the tibial component of total knee arthroplasty for the Korean population. Knee, 14(4):295-300, 2007.

Lim, L. C.; Bae, J. H.; Yoon, J. Y.; Kim, S. J.; Kim, J. G. \& Lee, J. M. Gender differences of the morphology of the distal femur and proximal tibia in a Korean population. Knee, 20(1):26-30, 2013.

Mahfouz, M.; Abdel Fatah, E. E.; Bowers, L. S. \& Scuderi, G. Three-dimensional morphology of the knee reveals ethnic differences. Clin. Orthop. Relat. Res., 470(1):172-85, 2012.

Moghtadaei, M.; Moghimi, J.; Farahini, H. \& Jahansouz, A. Morphology of proximal tibia in Iranian population and its correlation with available prostheses. Med. J. Islam. Repub. Iran, 29:225, 2015.

Oliveira Costa, A. C.; Feitosa de Albuquerque, P. P.; de Albuquerque, P. V.; Ribeiro de Oliveira, B. D.; Lima de Albuquerque, Y. M. \& Caiaffo, V. Morphometric analysis of the scapula and their differences between females and males. Int. J. Morphol., 34(3):1164-8, 2016.

Rabbi, R. Determinação do Sexo atraves de Medições em Ossos da Pelve de Esqueletos Humanos. Tese Mestrado em Odontologia Legal e Deontologia. Piracicaba, Faculdade de Odontologia de Piracicaba, Universidade Estadual de Campinas, 2000.

Rogers, T. L. Determining the sex of human remains through cranial morphology. J. Forensic Sci., 50(3):493-500, 2005.

Stranding, S. Gray Anatomia: A Base Anatômica da Prática Clínica. 40a ed. Rio de Janeiro, Elsevier, 2010.

Walrath, D. E.; Turner, P. \& Bruzek, J. Reliability test of the visual assessment of cranial traits for sex determination. Am. J. Phys. Anthropol., 125(2):132-7, 2004.

\author{
Corresponding author: \\ Vitor Caiaffo \\ Av. Oswaldo Cruz, n. 272 - Ap. 1301 \\ Maurício de Nassau \\ Caruaru, PE \\ ZIP: 55012-040 \\ BRAZIL
}

E-mail: vitor.caaufpe@gmail.com

Received: 11-07-2017

Accepted: 13-10-2017 